UDC 811.111'36:811.163.41'36

https://doi.org/10.18485/bells.2018.10.7

\author{
Ivana Trbojević Milošević \\ University of Belgrade \\ Faculty of Philology \\ Belgrade, Serbia
}

\title{
CORPUS EVIDENCE FOR EVIDENTIALS IN ENGLISH AND SERBIAN POLITICAL INTERVIEWS
}

\begin{abstract}
The article presents a small-scale contrastive analysis of evidential markers carried out on a sample of political interview discourse in English and Serbian. Methodologically, the so-called independent approach in contrastive analysis is taken, as the research starts from the notion of evidentiality as a tertium comparationis and looks for its linguistic expressions in two corpora of political statements, interviews and speeches given by prominent English (speaking) and Serbian politicians over a period of three years (2014-2017). The approximate size of the corpus is 150,000 words; it consists of 20 samples for each language, the average sample length being around 3000 words.

On the theory front, the article tries to bridge the gap between the two opposing schools of thought concerning the status of evidentiality - whether it is a linguistic category in its own right (Aikhenwald 2004, Cornillie 2009, Popović 2010) or whether it can be subsumed under epistemic modality (Chafe 1986, Palmer 1986). Evidentiality in this paper is understood in its 'broader' sense: evidentials are taken to be linguistic markers that indicate the speaker's type of evidence for her claim and/or degree of its reliability, probability or certainty (Diewald \& Smirnova 2010: 159). Therefore, the linguistic exponents of evidentiality investigated in the paper are taken to be expressions of interactants' epistemic stance, spanning
\end{abstract}

E-mail address: ivanatrbojevic@sbb.rs 
a value-range from full commitment to full detachment. Within the framework of interactive modality, epistemic stance may be viewed as an expression of speaker/writer attitudes residing not only in individual speakers/writers, but being dynamically constructed in response to the interactional requirements of the social/situational context and aiming at either establishing or disclaiming responsibility and authority. For this reason, they may be considered 'evidential strategies' (Aikhenvald 2014).

The aim of the research is at least fourfold:

1. to identify, describe and classify the markers of evidentiality in the discourse of English-speaking and Serbian politicians;

2. to identify patterns in the evidential strategies used by the speakers in this particular type of discourse;

3. to compare the relative frequencies of occurrence of the evidential markers and the strategies behind them in order to draw inferences of (intercultural) pragmatic nature;

4. to establish contrasts and similarities in the patterning of evidential strategies used in constructing social meaning in the discourse of politics in order to draw inferences of a typological nature.

Key words: contrastive analysis, corpus, discourse, epistemic stance, evidentiality, evidential strategy, frequency

\section{Theoretical background}

\subsection{Evidentiality and epistemic modality}

Although evidentiality as a formal, functional and semantic category has been thought about and written about sporadically for practically a century (Jespersen 1924 on 'indexical particles', Boas [1911] 1947, Jacobson 1957 on 'shifters', Lee 1959), only since 1986, when Chafe and Nichols edited Evidentiality: The linguistic coding of epistemology, has evidentiality, grammatical or lexical marking of source of information presented in a proposition, become a subject of systematic research and debate in contemporary linguistics, primarily owing to intensive crosslinguistic and typological studies. Quite inevitably, the focus on the source of knowledge and information to be presented in an utterance has related evidentiality to other notions, especially to those concerning the speaker's attitude towards the epistemic status of the information presented, i.e. to the domain of epistemic modality. Recognition of such a close relation has come naturally, since both domains - that of evidentiality and that of 
epistemic modality - make use, at least to a certain degree, of similar, if not the same linguistic markers. However, it also sparked a dispute over the nature of this relation, especially over the primacy of one category over the other, which, in turn, led to three different views, which, inspired by the division offered by Dendale and Tasmowski (2001) I shall refer to as 'exclusivist', 'inclusivist' and 'intersecting'. The first was held by those linguists who saw the domains of evidentiality and modality as separate, strongly maintaining that only languages that feature explicit grammatical means of marking the source of information and mode of knowledge acquisition have the category of evidentiality (most notably Aikhenvald 2004, but also Cornillie 2004, though his views have evolved in a different direction lately, and Popović 2010). Even so, they admitted to the existence (in languages with no grammaticalized markers of evidentiality) of linguistic expressions marking the knowledge/information source lexically ('evidential strategies'). The 'inclusivist' view acknowledged the relation between evidentials and the reliability of the speaker's knowledge and consequently related it to the degree of the speaker's commitment to the propositional content (i.e. modality). However, the 'inclusivist' view ramified in two directions: one that considered modality as part of the semantic scope of evidentiality (Mithun 1986, Matlock 1989), and another, rather prevalent for a certain period of time, that saw evidentiality as a 'type of' epistemic modality (Palmer 1986, Willet 1988) or that acknowledged the relevance of evidentiality in defining epistemic modality (Nuyts 2001). The third camp, most prominently van der Auwera and Plungian (1998), claimed that evidentiality and epistemic modality 'overlapped' or 'partially intersected' (Dandale \& Tasmowski 2001), particularly in the 'inferential' domain (most notably in modal verbs, such as MUsT, where evidence provides premises enabling deduction or, to some extent, in mental predicates such as THINK and BELIEVE). In recent years, work and research by Boye (2012) has reconciled the opposing camps quite successfully by arguing that both domains, that of evidentiality and epistemic modality, represent subdomains of a superordinate category of epistemicity.

The primacy dispute - of either modality or evidentiality over the other - developed as a result of the fact that both evidentiality and epistemic modality had (or rather have) been understood in their broader and narrower senses, both domains being particularly difficult to define. It is the holders of 'exclusivist' views that mostly understand evidentiality in its narrower sense, i.e. as grammaticalized markers of the source of information and the 'mode of knowing'. Still, even the most fervent 
advocates of evidentiality as a category in its own right admit to 'epistemic extensions' of evidentiality and evidentiality strategies. It is in this broader sense that I will regard evidentiality in this paper.

If the understanding of epistemic modality is narrowed to the chances, likelihood or probability that some state of affairs will, is or has become actualized (Nuyts 2001), the speaker who assesses such chances, likelihood or probability (and therefore takes an epistemic stance) is taken out of the picture; though such an understanding of epistemic modality presupposes the existence of premises upon which inference is drawn, it is not surprising that epistemic modality is taken to be a separate category from evidentiality.

A broader understanding of epistemic modality, as the speaker's commitment regarding the truth of the proposition, inextricably relates evidentiality to modality, without necessarily subsuming one under the other. Making an epistemic qualification of the propositional content, or passing an epistemic judgment, is inferential in nature; as said above, it presupposes the existence of premises upon which inference is drawn. The nature of premises, or 'mode of knowing', however, can be experiential (therefore, evidential) or rational (encyclopaedic).

In the epistemically qualified utterance

(i) Lola must be at home. The light's on.

the speaker relies on direct sensory, visual evidence (standing in the street and looking at Lola's lit window) - she can see, and her first-hand perception ('I can see') serves as the basis for the premise 'the light's on'. Visual evidence acquired through direct, first-hand perception is as reliable as it can be, but still not sufficient to allow for strong inference as in (i): at least one more premise is necessary for the speaker to infer (i), i.e. ' $[I$ know] Lola lives here'; the other premise must be at least as reliable to allow for an inference of such strength (i.e. 'Lola must be home '). The other premise originates in the speaker's knowledge of the reality around her. The strength and reliability of visual evidence as well as the reliability of the other premise (knowledge of the fact [Lola lives here]) determine the strength of the epistemic judgment, i.e. the strength, or degree, of the speaker's commitment to the truth of the proposition 'Lola is at home'; in other words - the strength of both premises will shape the speaker's epistemic stance. 
Ivana Trbojević: Corpus Evidence for Evidentials in Serbian and English Political Interviews

The 'interaction' of the epistemic and evidential qualification "in the sense that epistemic qualification is based on the quality and status of sources (evidence)" (Nuyts 2001: 35), as well as van der Auwera \& Plungian's (1998: 85) welcoming of "the subtype of evidentiality termed 'inferential"' (i.e. acquiring evidence through reasoning), justify the view that I shall hold here and that I shall call 'interfacing': evidence (direct or indirect, sensory/experiential, reportive or rational / encyclopaedic), provides the [necessary] epistemological basis upon which epistemic judgment of the proposition is offered. In other words, there is no epistemic qualification of the utterance unless there is some kind of evidence, no matter whether its nature is direct (perceptual) or rational. Evidentiality, then, can be said to 'precede' or 'underlie' epistemic modality; the two domains are therefore related, but the relation is not and should not be understood as a 'type-of' hierarchy. The 'interfacing' relation between evidentiality and epistemic modality allows for 'evidential strategies' to be interpreted as stance markers in discourse, as will be explored in this article.

At this point, it is worth noting that evidentiality markers do not necessarily trigger the taking of an epistemic stance - they prototypically mark the source of information or mode of knowing and often do only that. Take the following dialogue between A and B:

B: The Smiths left the UK for good.

A: How do you know?

B: My mother-in-law told me.

The focus of A's question is the source of the information / the mode of B's knowing, and the evidentiality marker remains just that - a marker of the source of information. ${ }^{1}$

1 Even so, it can be argued that speaker A requests verification of the truth of the proposition 'The Smiths left the UK for good' and needs to check the reliability of the source. Though her utterance in form is rogative, it can be interpreted as a dubitative speech act, and therefore epistemic. On speaker B's side, the reportive marker (told me) may trigger the implicature [and she is a trustworthy source]. However, this analysis would require the building of much more context, so I would rather take the reportive verb as a 'pure' evidentiality marker. 


\subsection{Epistemic stance}

The construct of stance presents no less of a challenge in linguistic literature than the related concepts of evidentiality and epistemic modality. Extensive research of stance has related it to hedging, vague language, evidentiality, modality, attitude, and affect. Biber and Finegan (1989) and Biber et al. (1999) differentiate between three categories of stance: epistemic, which relates to the state of speakers' knowledge in terms of certainty, doubt, actuality, source of knowledge, imprecision, viewpoint and limitation; affect, which relates to emotions, attitudes, states and evaluations; and manner, or rather, the style of speaking. In this study, I shall focus on markers of epistemic stance understood as the measure or function of speaker's modality whose epistemological basis is (at least in part) evidential. Also, within the framework of interactive modality (Nuyts 2001), epistemic stance is viewed as an expression of speaker/writer attitudes, residing not only in individual speakers/writers, but being dynamically constructed in response to the interactional requirements of the social/situational context and aiming at either establishing or disclaiming responsibility and authority. Such an understanding of epistemic stance becomes particularly suited to the research of evidential expressions as markers of epistemic stance in the discourse of political interviews presented below.

Relying on a deictic account of epistemic modality, I shall adopt the view that stance is conceptualized as distance between the expressed and reference worlds ${ }^{2}$ (Chung \& Timberlake, 1985); also, depending on the status of the information / knowledge, which can be direct or indirect and therefore more or less reliable / unreliable, stance can take values on the distance gradient, spanning a value-range from full commitment to full detachment (to and from the truth of the propositional content). A proportional relation establishes itself here: the directness and reliability of knowledge stand in direct proportion. In other words, the more direct the evidence, the more reliable the mode of knowing. On the other hand, the more direct/reliable the knowledge is, the stronger speaker's commitment to the propositional content, which stands in inverse proportion to the distance between the expressed and reference worlds - the closer the distance, the stronger the commitment to the propositional content and vice versa. Therefore, 'I know that p' (based on reliable evidence) encodes the closest possible distance, where the expressed world and the reference

2 i.e. between the speaker's epistemic modal qualification and the proposition content. 
world practically converge. Practically, but not quite: 'I know' still explicitly points to the status of knowledge - the epistemic stance then takes the lowest value on the distance gradient.

\subsection{Scalar nature of epistemic stance}

That stance may take different values on the distance gradient points to its scalar nature, within and across evidential categories and paradigms. The two basic categories of evidentials are defined according to the directness of access to knowledge/information (Willet 1988): knowledge is directly accessed through perception (primarily through the visual mode, but others as well); while indirectly, knowledge is accessed either through reports by others, or is arrived at through the process of reasoning/inference.

A. Direct access (through perception; sensory evidence)

B. Indirect access, either through:
a. Reports from others (hearsay; quotative)
b. Reasoning (inferential evidence)

(Papafragou et al. 2007: 256)

It seems that cross-linguistic research into evidentials has established that evidential subcategories form a scale defined by the reliability of the information source/mode of knowing; direct evidence (especially that acquired through visual perception) ranks the highest and much above the reliability of inferred evidence.

i) 'It's raining heavily outside, I can see it' ranks higher in terms of reliability than

ii) 'I can hear the rain outside' which triggers implicature [but I haven't seen it].

Both rank higher than

iii) 'I've been told it's raining outside'.

Reasoning such as

iv) 'The coat-stand is full of dripping raincoats - I guess it's raining outside' 
should rank the lowest, as the circumstantial evidence may prove to be a wrong premise [everybody's raincoats got wet because the sprinklers in the elevator went off by accident].

Within the three main subcategories of evidentials, the scalar values that the epistemic stance takes may be illustrated as follows:

a) Sensory evidence paradigm

a1. Well, I entered the race because I really saw that this district needs a representative very quickly.

a2. Well, I entered the race because it seemed to me that this district needs a representative very quickly.

a3. Well, I entered the race because it sounded to me that this district needs a representative very quickly.

\begin{tabular}{lcc}
\hline \multicolumn{1}{c}{ Stance value a1-a3 } & Reliability a1-a3 & Distance on gradient \\
\hline Strong $^{3}$ & High & Close \\
Weaker & Lower & Farther \\
Weak $^{4}$ & Low & Far \\
\hline
\end{tabular}

Table 1.

b) Reportive evidence paradigm

b1. Well, I entered the race because many people insisted that this district needs a representative very quickly.

b2. Well, I entered the race because many people said that this district needs a representative very quickly.

b3. Well, I entered the race because rumour had it that this district needs a representative very quickly.

3 Shows commitment.

4 Shows detachment. 
Ivana Trbojević: Corpus Evidence for Evidentials in Serbian and English Political Interviews

\begin{tabular}{lcc}
\hline Stance value b1-b3 & Reliability b1-b3 & Distance on gradient \\
\hline Strong & High & Close \\
Weaker & Lower & Farther \\
Weak & Low & Far \\
\hline
\end{tabular}

Table 2.

c) Inferential evidence paradigm

c1. Well, I entered the race because I really knew that this district needs a representative very quickly.

c2. Well, I entered the race because I assumed that this district needs a representative very quickly.

c3. Well, I entered the race because I thought/believed that this district needs a representative very quickly.

\begin{tabular}{lcc}
\hline Stance value c1-c3 & Reliability c1-c3 & Distance on gradient \\
\hline Strong & High & Close \\
Weaker & Lower & Farther \\
Weak & Low & Far \\
\hline
\end{tabular}

Table 3.

\subsection{Evidence, epistemic stance and (inter)subjectivity ${ }^{5}$}

Another dimension of evidence that influences the speaker's stance and that needs to be included in any account of it is one of intersubjectivity. ${ }^{6}$ Epistemic qualifications of a state of affairs are necessarily subjective if the speaker herself is the source of knowledge. According to Nuyts $(2000,2001)$,

5 The term (inter)subjectivity stands for the opposition subjectivity vs intersubjectivity.

6 Intersubjectivity is first mentioned in Benveniste (1971, in Traugott \& Dasher 2002), where he draws a distinction between the notions of subjectivity and intersubjectivity and the latter is seen as ground for linguistic communication within the speaker-hearer dyad. His views largely influenced further elaborations of the opposition subjective vs intersubjective and departed from traditional semantic and philosophical accounts of subjectivity/objectivity. 
intersubjectivity is a dimension of evidence/knowledge that is accessible to, known to or shared by a larger group of people, who, consequently, arrive at the same epistemic qualification of the information. It also implies that the speaker knows about the hearers' epistemic evaluations of the information presented, or even that they are generally known (Traugott and Dasher 2002). For that reason, unlike subjective expressions of stance, (in which the speaker takes full responsibility for her claims), in intersubjective ones the speaker's commitment may get so 'blurred' and hidden that they become almost descriptive. Therefore, intersubjectivity is often used as a pragmatic and discursive strategy when the speaker tries to reduce her responsibility for what she says. (Inter)subjectivity, therefore, stands in relation to the source of knowledge (the speaker or others/ individual or collective) and concerns the state of evidence in the interaction.

Within the three main categories of evidentials, (inter)subjectivity varies: in the sensory evidence paradigm, both realizations are possible - subjective ('I see [that]', 'I hear [that]', 'I feel [that]') and intersubjective ('we hear [that]', etc.); in the inferential evidence paradigm, again, stance will be marked for subjectivity in expressions such as 'I think [that]' or for intersubjectivity when the premises are shared and inference carried out by many ('we know [that]', 'we think [that]', etc. As for the reportive evidence paradigm, the speaker stance is either neutral or could be taken as intersubjective (if intersubjectivity includes the speaker's knowledge of other people's epistemic qualifications of the state of affairs), as in 'It is said [that], It is generally known [that]'.

\subsection{Evidentiality, epistemic stance and discourse modality}

In languages like English and Serbian that do not have anything close to a grammaticalized system of evidence markers, marking the source of information /knowledge, i.e. evidential marking is not formally obligatory. However, in both languages (as in many others), speakers often resort to lexical markers of evidentiality in discourse, which means that their use is motivated and purposeful. By using markers, speakers do something to the content of the message they are sending to the interlocutors, readership, audience, viewers or general public. Depending on the situational context, speakers deliberately and strategically take care to preserve their face, credibility, integrity or authority and (among other means) they can do so by reaching out for evidential markers, which Aikhenwald (2004) 
Ivana Trbojević: Corpus Evidence for Evidentials in Serbian and English Political Interviews

so conveniently terms "evidentiality strategies". Another theoretical framework, which is detached from propositional modality, comfortably accommodates and accounts for such strategies in discourse - namely Maynard's (1993) concept of discourse modality. This framework takes into account "the speakers' subjective, emotional, mental or psychological attitude toward the message content, the speech action itself or toward his/her interlocutor in discourse" (Maynard 1993: 38). Discourse Modality Indicators take various linguistic forms and comprise four different aspects : 1) information qualification, 2) speech act declaration and qualification, 3) participatory control and 4) interactional appeal. For the purposes of this research, I shall focus specifically on 1), i.e. how markers of evidentiality qualify information in terms of epistemic stance towards achieving a higher or lower degree of personalization/impersonalization of the discourse in question. Within the combined frameworks of interactive and discourse modalities, I shall regard epistemic stance as an expression of speaker/ writer attitudes, residing not only in individual speakers/writers, but being dynamically constructed in response to the interactional requirements of the social/situational context and aiming at either establishing or disclaiming responsibility and authority.

\section{Research and corpus data}

The aim of the research presented in the article was fourfold:

1. to identify and classify the markers of evidentiality in the discourse of English-speaking and Serbian politicians in the sampled political interviews;

2. to compare the relative frequencies of occurrence of the evidential markers and the strategies behind them in order to draw inferences, if possible, of (intercultural) pragmatic nature;

3. to identify patterns in the evidential strategies used by speakers/participants in this particular type of discourse (interviewers and interviewees);

4. to establish contrasts and similarities (Bugarski 1991) in the patterning of evidential strategies used in constructing social meaning in the discourse of politics in order to draw inferences of a typological nature. 
For the purposes of this research, two smaller corpora were compiled; both consist of samples of interviews and commentaries from AngloAmerican and Serbian media (interviews in quality weeklies and transcripts of TV interviews); both corpora cover the same topics (election campaigns, economic reforms, political affairs, and religious issues, in interviews with high-ranking politicians, business people and people active in the respective socio-cultural settings).

The samples were collected randomly and cover a period of three years (2014-2017). The approximate overall size of the entire corpus is 150,000 words; each subcorpus consists of 20 samples, the average sample length being around 3,000 words. The English corpus is somewhat larger (around 77,000 words), while the Serbian corpus amounts to approximately 73,000 words. Altogether, there are 31 speakers whose linguistic output has been examined for evidential markers (11 interviewers and 20 interviewees, since some interviews were carried out by the same journalist; there are 6 male and 5 female interviewers, and 10 male and 10 female interviewees). Since the interviews vary considerably in length (some amount to more than 5,000 words, while some are less than 2,000 words long), the frequency of occurrence of the evidential markers has been normalized to 1,000 words and represented as f/1000 wds.

\section{Findings}

Through observing the criteria that the markers need to indicate and qualify the source of information, to be deictic in nature (in the sense that they encode greater or less distance towards the propositional content) and therefore signal the speakers' epistemic stance with the ultimate effect of constructing social meanings in discourse through its personalization/ impersonalization, a number of lexical markers that qualify the source of information/mode of knowing were identified in both corpora:

1. Verbs (lexical) ${ }^{7}$ (including the very rare, in fact insignificant occurrence of modal verbs as evidence markers) - by far the most preferred type of evidentiality markers in both corpora;

\footnotetext{
7 Although I expected to find a more significant presence of modal verbs such as the English must / Serbian morati, I identified only one occurrence of epistemic/evidential must followed by the perfect infinitive.
} 
Ivana Trbojević: Corpus Evidence for Evidentials in Serbian and English Political Interviews

\section{Adverbs}

3. Adjectives

4. Nominal phrases and phrases of clausal origin ${ }^{8}$

The verbs identified as evidentials in the corpora are marked for person, number, tense, aspect and voice, and are occasionally further modified by means of distal modals in the English corpus; the verbs in the Serbian corpus are marked for the same/or equivalent grammatical categories, such as the 'impersonal active construction', or non-indicative moods, such as Potential ${ }^{10}$. Apart from encoding their primary grammatical meanings, the formal markers also contribute to signalling epistemic stance dimensions, such as distance/commitment and (Inter)subjectivity. The person marking in the verbs that occur in the corpus (especially the choice between $1^{\text {st }}$ person singular, $1^{\text {st }}$ person plural and $2^{\text {nd }}$ person) is particularly important to follow throughout the interviews, as it reveals the (inter)subjective dimension of the markers chosen to signal the speakers' stance, and, in consequence, it allows the recognition of signals of personalization or impersonalization, i.e. of the speakers' participatory control in terms of responsibility, and authority. The person marking will be commented on in subsections 3.1.and 3.2., where the distribution of evidential markers between the participants in the interviews is discussed.

\subsection{Frequency of the evidentiality markers in the corpus}

The frequency of the chosen evidentiality markers was found to be fairly balanced between the two corpora: in the English corpus, the normalized frequency was 8.5 per 1000 words (ptw), whereas in the Serbian corpus it was $8.1 \mathrm{ptw}$. The difference in frequency is too slight to point to any distinctive cultural differences as regards the use of evidentiality markers to signal epistemic stance (like tentativeness or hedging), although I did

8 See Tables 4. and 5. below for the full list of evidential items identified in both corpora.

9 Impersonal construction (e.g. 'priča se' [da] (it is being said[that]) ) formed by adding the reflexive clitic/particle 'se' to the transitive or intransitive verb, sometimes referred to as 'impersonal active'.

10 What English achieves in terms of epistemic distance encoding by means of distal modals, Serbian does by the grammatical finite verbal form of Potential or Conditional; unlike English, through the Potential Serbian can encode distance directly on the lexical verb. 
expect the difference to be greater, considering the Serbian preference for directness and the English preference for indirectnes.

Also, I assumed that my corpus findings would show a more significant difference in the use of evidentiality markers to signal a weaker epistemic stance in female than in male speakers of both languages. But it turned out that the frequency of the evidentiality markers chosen by the speakers of both languages varies insignificantly between males and females, and, quite opposite to my expectations ${ }^{11}$ the men used more evidentiality markers as signals of stance than the women; in the English corpus, the men used $9.4 \mathrm{ptw}$, and the female speakers $7.7 \mathrm{ptw}$. In the Serbian corpus, the difference is even less marked, as the male speakers used 8.6 evidentiality markers ptw, and the female speakers $7.6 \mathrm{ptw}$. This even balance of evidentiality markers to signal stance may be explained by the equality of the social roles that interviewers and interviewees assume in the situation of conducting/giving an interview, a role that is not affected by the gender of the participants.

However, a closer look at the frequency and distribution of the individual classes of markers reveals interesting differences and insights. Of all the evidential markers (sensory, reportive and inferential), the non-factual mental state predicate THINK turned out to be the speakers' most frequent choice in both corpora; the non-factual BELIEVE and the factual know followed, but were not as frequent and their frequency was not as balanced between the two corpora as in the case of тHINk. The English speakers showed greater preference for KNow than BELIEve, while the order was reverse in Serbian, where instances of VEROVATI ('BELIEVE') outnumbered instances of zNATI ('KNOW'). The frequency of KNOw in the English corpus (KNOw primarily signalling the self as the source of information/mode of knowing) was such that I thought it might be a signal of greater self-confidence and authority of the speakers in question.

11 True enough, my expectations of women expressing a weaker epistemic stance and thus greater insecurity and less self-confidence as a consequence of their subdued social position have been influenced by rather blanket assertions in gender-oriented studies in linguistic pragmatic literature; these assertions have in fact been proven wrong in a number of corpus-based studies. 


\begin{tabular}{|c|c|c|}
\hline Sensory & Reportive & Inferred \\
\hline $\begin{array}{l}\text { Verbs } \\
\text { See (12) } \\
\text { Feel (6) } \\
\text { Hear (3) } \\
\text { (Seem (12)) } \\
\text { Look (9) } \\
\text { Sound (3) } \\
\text { Recognize (1) }\end{array}$ & $\begin{array}{l}\text { Verbs } \\
\text { Say (51) } \\
\text { Tell (3) } \\
\text { State (3) } \\
\text { Talk (about) (3) } \\
\text { Show (3) } \\
\text { Advocate (2) } \\
\text { Indicate (1) } \\
\text { Point (1) } \\
\text { Insist (1) }\end{array}$ & $\begin{array}{l}\text { Verbs } \\
\text { Think (114) } \\
\text { Know (27) } \\
\text { Believe (15) } \\
\text { (Seem (12)) } \\
\text { Guess (3) } \\
\text { Hope (2)) } \\
\text { Deem (1) } \\
\text { Must (have been) (1) }\end{array}$ \\
\hline $\begin{array}{l}\text { Adverbs } \\
\text { Obviously (9) } \\
\text { Clearly (6) } \\
\text { Actually (6) }\end{array}$ & $\begin{array}{l}\text { Adverbs } \\
\text { Allegedly (3) }\end{array}$ & $\begin{array}{l}\text { Adverbs } \\
\text { Consequently (1) }\end{array}$ \\
\hline $\begin{array}{l}\text { Adjectives } \\
\ldots \ldots . .\end{array}$ & $\begin{array}{l}\text { Adjectives } \\
\text { So-called (1) }\end{array}$ & $\begin{array}{l}\text { Adjectives } \\
\text {........ }\end{array}$ \\
\hline
\end{tabular}

Other: based on our statistics/study/research; according to the polls/report, rumour has it; following XY; it is common knowledge [that]

Table 4. English corpus: evidential instances in 77,000 words

However, a closer reading of the utterances in which this inferential marker occurred showed that in only a small number of instances (4) was KNOw used with the $1^{\text {st }}$ person singular pronoun signaing the speaker as the source of information/knowledge and thus maintaining the authoritative voice in the discourse, as in:

vi) I know that he is very eager to hear what all of us (....) think. In two instances, negated kNow was used with the $1^{\text {st }}$ person singular pronoun, as in:

vii) I don't know whether that's an accurate historical perception.

In these utterances, the speaker signalled a strong detachment from the propositional content, and consequently took a weak epistemic stance, which could not contribute to her authoritative voice. 
In all the other instances of kNow used to mark evidentiality in the English corpus, the verb was either marked for the $2^{\text {nd }}$ person ${ }^{12}$ or for the $1^{\text {st }}$ person plural:

viii) [...] you know Hezbullah has operatives all throughout Latin America...

ix) [...] we also know that we have to begin networking more effectively with a lot of other people and institutions.

In this way, the subjectivity dimension is shifted to intersubjectivity; the speaker disowns herself of the information/knowledge and presents it as collective and shared and reduces her responsibility, so the stance, in a way, takes a neutral value. The authority of the speaker is preserved as part of collective authority. Throughout the interviews, the speakers rate the information content by importance and the possible consequences it may have on their credibility, integrity, responsibility etc. and alternate the person marking accordingly.

On the whole, markers of inferential evidentiality were the most frequent in both corpora, then came markers of reportive evidentiality, with sensory evidentiality markers in third place. ${ }^{13}$

On the Serbian side, the figures reveal a very similar picture: in the sensory evidentiality column, the equivalents of FEEL and sound were not found in the corpus, but the number of visual perception verbs SEE/ VIDETI was the same, with approximately the same ratio of shift from subjectivity to intersubjectivity as in the English corpus, as well as in the semi-copulative SEEM $^{14}$ (see Table 5 . below). As already mentioned above, the most frequently used evidentiality marker was the mental predicate MISLITI/THINK, whose frequency of occurrence topped not only the inferential evidentiality column, but outnumbered all other markers.

12 Not as a parenthetical discourse marker 'you know' - these occurrences were not taken into account.

13 Given the nature of the discourse examined and the cognitive and semantic potential of the verbs of perception, it can also be argued that the sensory verbs are actually used as markers of reasoning and inference, but for the purposes of this research I shall keep the distinction as presented above.

14 Serbian shows a little bit more variety, but the verbs IZGLEDATI, ČINITI SE, DELOVATI all share the meaning of SEEM. 


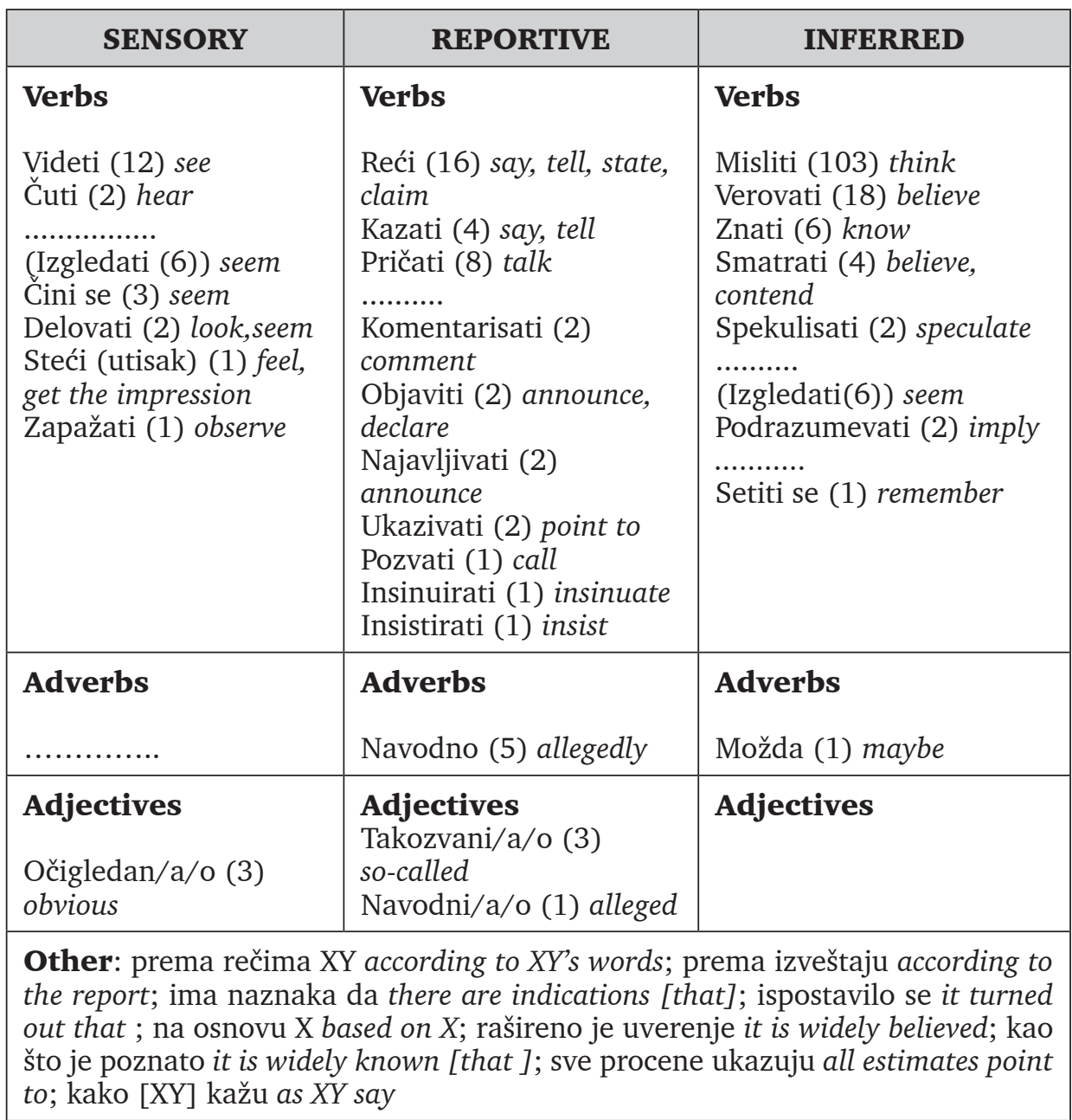

Table 5. Serbian corpus: evidential instances in 73,000 words

\subsection{Distribution of evidentiality markers between the interactants in the discourse}

As mentioned above, the data obtained for both corpora present a balanced contrastive picture for the two languages. However, the picture gets more complex and reveals certain patterns of the interactants' behaviour when the distribution of evidentiality markers is analyzed in the interviewers' and 
interviewees' discourses respectively. I shall present the findings for the English and Serbian interviewers first, and then do the same for the interviewees. As will be shown, the basic contrast in evidentiality marker usage to signal the speaker's epistemic stance does not lie between the two languages, but rather between the interactants, namely the interviewer and the interviewee.

\subsubsection{Distribution: English interviewers}

The frequency of evidentiality markers in the English interviewer subcorpus was higher than the figures for the entire English corpus - it rose to slightly over $10 \mathrm{ptw}$ (compared to $8.5 \mathrm{ptw}$ ). This can be accounted for by the size of the interviewer subcorpus - interviewers' portion constitues approximately $25 \%$ of the text - the rest is produced by interviewees.

By far the most frequent evidentiality markers in the interviewers' turns were the reportive verbs SAY, TELL, and SHOw, followed by SEEM; the verbs were marked for either $2^{\text {nd }}$ or $3^{\text {rd }}$ person (singular and plural); also, they often appeared in non-agentive passive constructions, or if active, the agents were indefinite; occasionally they were further modified by distal modal verbs:

x) You said that you'd had two, in fact...

$\mathrm{xi}$ They said that was what $[\mathrm{XY}]$ would want to say

xii) Polls show that...

xiii) Some seem to be advocating...

xiv) I was told that...

xv) Some would say that...

By using reportive markers, the speakers (interviewers) maintain a steady detachment, or distance, from the propositional content, as they try to avoid subjectivity and strive to achieve objectivity and neutrality of stance; the passive and prevalent markedness for the $2^{\text {nd }}$ and $3^{\text {rd }}$ person, as well as pointing to indefinite agents as the source of information/ knowledge further mark the distance towards the propositional content and produce the effect of an impersonalized tone in the discourse (see Figure 1. below)

The occurrence of other classes of evidentiality markers in the interviewers' discourse was quite rare; out of the rather wide range of inference markers, the subjective THINK, for instance, appeared only once in the entire English interviewer subcorpus: 
xvi) I think you know [that the ratings...]

signalling, again, a weak epistemic stance; and, from the sensory class, sound occurred once:

xvii) Sounds to me [as if...]

where the interviewer also takes a subjective, weak and personalized stance.

Similarly, the adverbs from the sensory class, apart from single occurrences of CLEARLY, OBVIOUSLY and ACTUALLY, were all used by the interviewees. No occurrences of reportive adverbs and adjectives (ALLEGEDLY, SO-CALLED) were noted in the English interviewer subcorpus.

\subsubsection{Distribution: Serbian interviewers}

The frequency of evidentiality markers in the Serbian interviewer subcorpus was somewhat lower than in the English one - around 9 ptw; still, the pattern of the interviewers keeping a steady stance by predominantly using reportive verbs was repeated. The range of lexical reportive verbs in the Serbian interviewer subcorpus was somewhat wider than in English, as the manner of delivering the information by the source is more specified (komentarisati/ comment, insistirati/insist, pozvati/ appeal, call, ask objaviti/announce etc).

xviii) [građane] ste pozvali na strpljenje i najavili donošenje teških odluka... ${ }^{15}$

Although the reportive evidential strategies themselves signal detachment from the propositional content and a mid-value, neutral epistemic stance, the interviewers frequently 'reinforce' the distance by resorting to the 'impersonal active' and, occasional passive constructions, giving their discourse an impersonalized tone:
xix) Priča se $u$ javnosti [da]... ${ }^{16}$
xx) Na Vladi je rečeno [da]... ${ }^{17}$

\footnotetext{
15 You asked the citizens for patience and announced that serious decisions would have to be made...

16 Rumour has it that...

17 It was said at the Cabinet meeting...
} 
As in the English interviewer subcorpus, the subjects of these verbs were often indefinite agents, such as 'neki' (some), 'ljudi' (people) or 'mnogi ljudi' (many people). Not only do such strategies contribute to the impersonalization of the discourse tone, but they also imply the speaker is disclaiming responsibility for the content presented and, consequently, attempting to save face.

\subsubsection{Distribution: English and Serbian interviewees}

In both subcorpora, English and Serbian, the interviewees show the same pattern of stance taking: the predominant evidence markers fall into the inferential category (think, believe, know ; misliti, verovati, znati), with THINK / MISLITI having the highest number of occurrences. It is interesting to note that in both corpora, the inferential markers are practically encountered only in the interviewees' discourse (with the exception of the two examples mentioned above in 3.2.1.). Also, the semi-copulative SEEM / ČINITI SE (and other related indirect perception verbs in Serbian), which follow in terms of frequency, exhibit a very similar, practically identical pattern, revealing two types of strategies that differ in the (inter)subjective dimension, visible in the alternation of person marking between the $1^{\text {st }}$ person singular and $1^{\text {st }}$ person plural. As I have argued above, the $1^{\text {st }}$ person singular identifies self - as the source of information/knowledge, is subjective and suggests a weak epistemic stance, a greater distance towards the propositional content and consequently relieves the speaker of a portion of responsibility. The $1^{\text {st }}$ person plural, however produces a shift from subjectivity to intersubjectivity, pointing to a collective source of information/knowledge, and the shared knowledge implies further hedging from the propositional content and the speaker's responsibility also becomes shared. This ' $w e$ '-strategy is mostly exclusive of the interviewer, but inclusive of 'others of the kind' (voters, citizens, members of the Cabinet, party members, etc.).

By closely following the alternation of the $1^{\text {st }}$ person singular and $1^{\text {st }}$ person plural in the interviewees' answers (i.e. the shift from subjectivity to intersubjectivity) and the related stance changes (conceptualized as distance from or commitment to the propositional content), it is possible to observe the following pattern: when the interviewer's questions directly require the interviewee's opinion (as they usually do) on more sensitive or provocative topics that imply the interviewee's responsibility, the interviewee might 'oblige' by starting with 'I think' and switch to the $1^{\text {st }}$ 
Ivana Trbojević: Corpus Evidence for Evidentials in Serbian and English Political Interviews

person plural as early as the complement clause, or he/she immediately shifts to the intersubjective 'we':

xxi) So I do think we all believe we are the right side, aligning ourselves ...

xxii) But we think it is important to have the opportunity to make the case...

xxiv) Hoću da kažem da znamo da to šta radimo u ovim okolnostima... ${ }^{18}$

xxv) Smatramo da smo realno projektovali [ inflaciju]... ${ }^{19}$

The kNow markers in the English corpus have already been discussed in 3.1. In the Serbian subcorpus, the know marker was invariably used intersubjectively, either as the active $1^{\text {st }}$ person plural ( 'svi znamo' 'we [all] $k n o w$ '), the active $3^{\text {rd }}$ person plural ('svi znaju' 'everybody knows'), or in the construction with the adjective 'poznato' ('svima je poznato' 'it's known to everybody').

The Serbian interviewee subcorpus showed more occurrences of the reportive adverb 'navodno' (allegedly) and the adjective 'takozvani' (socalled). Although the terms 'navodno' / 'navodni/takozvani' originally do mark an unspecified and unverifiable source of information, and in that sense the speaker's low commitment to the propositional content, the interviewees in the Serbian subcorpus used them for qualifying purposes - to qualify the propositional content as false. They all occurred in the answers of high-ranking politicians commenting on criticisms and accusations coming from the opposition.

\section{Concluding remarks}

The analysis of the English and Serbian corpora of political interviews confirmed that the evidentiality markers resorted to by the interactants consistentlyqualified the epistemic stance towards theinformation presented in the interviews: both English and Serbian interviewees employed the same repertoire of markers to signal relative (un)reliability of evidence, shifting from subjectivity to intersubjectivity (and back) using the same formal signals (such as alternating between the grammatical persons and

18 I'd say that we know what to do...

19 We believe that we've made realistic estimates... 
accordingly alternating between expressing themselves in the personal or collective voice); marking indefinite agents as sources of information, the passive in English and corresponding impersonal active constructions in Serbian contributed to the personalization and impersonalization of the discourse.

Going back to the observed steady stance to the propositional content maintained by the interviewers (see 3.2.1 and 3.2.2), the pattern of the interviewer : interviewee interaction in both corpora could be graphically represented as in Figure 1 below (where $\mathrm{C}$ stands for the propositional content):

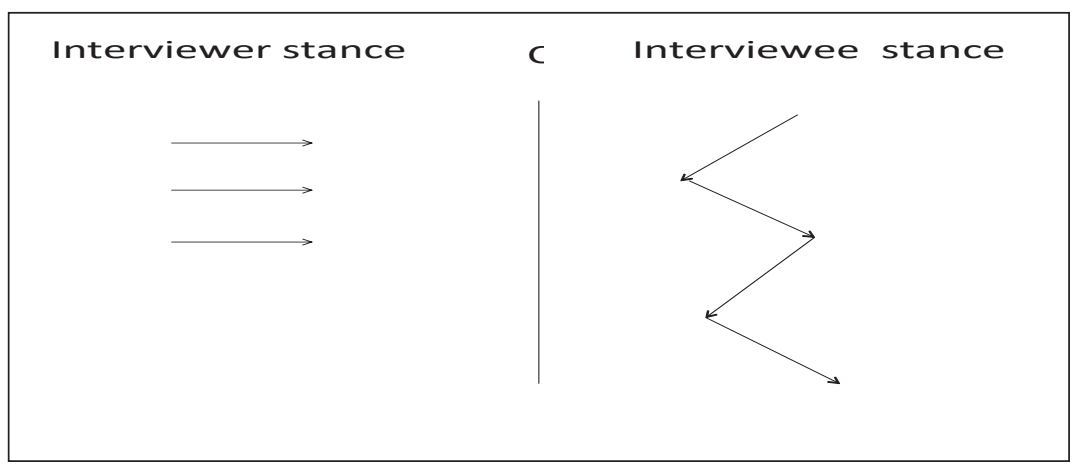

Figure 1.

The speakers' stance value conceptualized as distance from the propositional content (strong commitment - closer distance; weak commitment - farther distance) also accounts for the speakers' readiness to accept (share or shed) responsibility for the information presented; the same pattern was identified in both samples.

The findings and results obtained in the analysis of the two corpora lead to the conclusion that, if evidentiality strategy marking is taken to be the tertium comparations, contrastive analyses of evidentiality strategies as markers of epistemic stance and interactants' behaviour yield practically no contrasts or differences. My assumptions that the English would manifest a preference for indirectness and the Serbian a preference for directness have not been confirmed. On the contrary, the results rather suggest a conclusion in favour of the highest degree of typological similarity between the two languages in the domain of evidentiality marking. 
Ivana Trbojević: Corpus Evidence for Evidentials in Serbian and English Political Interviews

\section{References}

Aikhenvald, A. (2004). Evidentiality. Oxford. Oxford University Press Biber, D.and E.Finnegan (1988). Adverbial stance types in English. Discourse Processes 11, 1-34.

Biber, D. and E. Finnegan (1989). Styles of stance in English: Lexical and grammatical marking of evidentiality and affect. Text 9 (1), 93-124.

Biber, D., Johansson, S., Leech, G. Conrad, S. and E. Finnegan (1999). Longman Grammar of Spoken and Written English. New York. Longman.

Boas, F. (1947). Kwakiutl grammar, with a glossary of the suffixes. Transactions of the American Philosophical Society 37, 201-377.

Bugarski, R. (1991). Contrastive analysis of terminology and the terminology of contrastive analyis. In: V. Ivir and D. Kalogjera (eds), Languages in Contact and Conflict, Berlin / New York: Mouton de Gruyter, 73-92.

Chafe, W. (1986). Evidentiality in English conversation and academic writing. In: Wallace L. Chafe \& Johanna Nichols (eds), Evidentiality: The Linguistic Coding of Epistemology (Advances in discourse processes 20), Norwood. Ablex, 261-272.

Chung, S. and A. Timberlake (1985). Tense, aspect and mood. In: T. Shopen (ed.), Language Typology and Syntactic Description: Grammatical Categories and the Lexicon, Vol. 3, Cambridge: Cambridge University Press, 202-258.

Clayman, S. E. (2006). Speaking on behalf of the public in broadcast news interviews. In: Elizabeth Holt and Rebecca Clift (eds) Reporting Talk: Reported Speech in Interaction. Cambridge, U.K.: Cambridge University Press, 221-243.

Cornillie, B. (2009). Evidentiality and epistemic modality. Functions of Language, 16:1. Amsterdam. John Benjamins, 44-62.

Diewald, G. and E. Smirnova (eds) (2010). Linguistic Realization of Evidentiality in European Languages. EALT 49. De Gruyter Mouton.

Jacobsen, W. H. Jr. (1986). The heterogeneity of evidential in Makah. In: Wallace L. Chafe \& Johanna Nichols (eds), Evidentiality: The Linguistic Coding of Epistemology (Advances in discourse processes 20), Norwood. Ablex. 3-28.

Lee, D. (1959). Freedom and Culture. Englewood Cliffs, NJ: Prentice Hall. Matlock, T. (1989). Metaphor and the grammaticalization of evidential. Proceedings of the $15^{\text {th }}$ Annual Meeting of the Berkley Linguistic Society $15,215-225$. 
Maynard, S. (1993). Discourse Modality: Subjectivity, Emotion and Voice in the Japanese Language. Amsterdam. John Benjamins.

Mithun, M. (1986). Evidential diachrony in Northern Iroquoian. In: Wallace L. Chafe \& Johanna Nichols (eds), Evidentiality: The Linguistic Coding of Epistemology (Advances in discourse processes 20), Norwood. Ablex, 89-112.

Nuyts, J. (2000). Epistemic Modality, Language and Conceptualization. Amsterdam. John Benjamins.

Nuyts, J. (2001). Subjectivity as an evidential dimension in epistemic modal expressions. Journal of Pragmatics 33: 383-400.

Palmer, F. R. (1986). Mood and Modality. Cambridge. Cambridge University Press.

Papafragou, A., Lee, P., Choi Y. and C.Han (2007). Evidentiality in Language and Cognition. Cognition 103. 253-299.

Popović, Lj. (2010). Kategorija evidencijalnosti u srpskom i ukrajinskom jeziku [Category of Evidentiality in Serbian and Ukranian]. Zbornik Matice srpske za slavistiku 77. Novi Sad. 17-47.

Traugott, E. \& R. Dasher. (2002). Regularity in Semantic Change. Cambridge University Press.

van der Auwera, J. and V. Plungian (1998). Modality's semantic map. Linguistic Typology, Volume 2, 79-124.

Willett, T. (1988) A crosslinguistic survey of the grammaticalization of evidentiality. Studies in language 12, 51-97.

Received: 20 November 2017

Accepted for publication: 31 January 2018 
Ivana Trbojević: Corpus Evidence for Evidentials in Serbian and English Political Interviews

Ивана Трбојевић Милошевић

\section{ЕВИДЕНЦИЈАЛНЕ СТРАТЕГИЈЕ У ДИСКУРСУ ЕНГЛЕСКИХ И СРПСКИХ ИНТЕРВЈУА ПОЛИТИЧКЕ САДРЖИНЕ: ДОКАЗИ ИЗ КОРПУСА}

\section{Сажетак}

Овај рад представља резултате контрастивне анализе мањег обима у чијем су фокусу маркери евиденцијалног значења у узорку интервјуа политичке садржине на енглеском и српском језику. Методолошки, примењен је принцип 'независне контрастивне анализе', с обзиром да истраживање полази од појма евиденцијалности као 'трећег елемента поређења' и трага за језичким изразима евиденцијалности у два корпуса интервјуа политичке садржине које су дали истакнути англоамерички и српски политичари у периоду од три године (2014-2017). Укупна величина оба корпуса износи око 150.000 речи; састоји се од по 20 узорака за оба језика, при чему је просечна дужина узорка око 3.000 речи.

С теоријске стране, чланак покушава да премости јаз између две опречне школе мишљења у лингвистици а које се тичу статуса евиденцијалности - да ли је или не евиденцијалност формална граматичка категорија (Aikhenwald 2004, Cornillie 2009, Поповић 2010), односно да ли се може подвести под категорију епистемичке модалности (Chafe 1986, Palmer 1986). Евиденцијалност се у овом раду разуме у њеном 'ширем значењу': сматра се да су евиденцијали језички сигнали који указују на доказе којима се подржава говорников исказ у смислу његове поузданости, вероватноће и извесности (Diewald \& Smirnova: 2010: 159). Стога се језички експоненти евиденцијалности у овом раду схватају као изрази епистемичког става учесника у језичкој интеракцији, чија се вредност креће од пуне опредељености према истинитости пропозиције до потпуног одсуства опредељења. У теоријским оквирима интерактивне модалности, епистемички став се посматра као израз говорникових или пишчевих ставова који се динамички конструишу као одговор на интеракционе захтеве друштвеног/ситуационог контекста и којима се успоставља или одриче одговорност и ауторитет саговорника. Из тог разлога, ови се сигнали могу сматрати 'евиденцијалним стратегијама' (Aikhenvald 2014).

Истраживање има вишеструки циљ:

1. да идентификује, опише и класификује маркере евиденцијалности у интервјуима англоамеричких и српских политичара;

2. да открије обрасце у евиденцијалним стратегијама којима се служе говорници/учесници у овом типу дискурса; 
3. да упореди релативну фреквенцију јављања евиденцијалних маркера и стратегија како би се извукли закључци (интеркултурне) прагматичке природе;

4. да уочи контрасте и сличности између образаца евиденцијалних стратегија како би се извукли закључци типолошке природе.

Кључне речи: дискурс, евиденцијалност, евиденцијалне стратегије, епистемички став, фреквенција, контрастивна анализа, корпус 